\title{
MODIFYING AND EVALUATING OF THE LOCALLY \\ MADE WIND MILL FOR GROUND WATER LIFTING
}

\author{
* Prof. Dr. A. Y. Korayem, *Prof. Dr. M. M. Abou EI-Kheir, \\ *Prof. Dr. S. F. Ahamed \\ ,**Eng. F. D. Tawfeek
}

\begin{abstract}
Wind energy is utilized for ground water lifting to irrigate small area at the North West Coast of Egypt where there are several hundreds of windmills is use for this purpose. A survey was conducted on about one hundred windmills to investigate the intensity of their, use and problems encountered by farmers using these' windmills. The survey showed that the main problem was their small daily discharge especially during the low wind speed season. A solution of this problem can be achieved by reducing starting wind speed and increasing the discharge rate of the windmill. Three modification were attempted on a locally made windmill installed in a farm at Sidi Krere City, West of Alexandria. The first modification was replacing a (1 inch) diameter delivery pipe instead of standard one (1:5 inch), the second modification was using a counterweight device and the third modification was. using a two pumps mechanism. Tests showed that the first modification gave negative results on both the starting wind speed and the performance of the windmill, while the second modification was the best one reduce starting wind speed only and the third modification gave good results regarding starting wind speed and discharge rate where it was possible to increase the discharge rate by about $30 \%$ for wind speed for 3 to $4 \mathrm{~m} / \mathrm{s}$ and about $70 \%$ for wind speed from 7 to $8 \mathrm{~m} / \mathrm{s}$
\end{abstract}

Generally, the use of the third modification is one of the best solutions for increasing capacities of water lifting windmills which are used in the North West Coast especially and in low wind speeds regions

\section{INTRODUCTION}

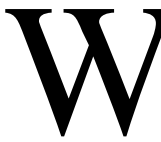

ith the decrease of the world stock of hydrocarbons the continually increased demand for energy presently, and the fear of expanding pollution, wind energy has come to the front.

* All Prof. Dr., Agricultural Engineering Dept. Faculty of Agricultural Alexandria University.

** Agric Engineer, B.sc in Agric Engineering 1990 
This type of energy is one of the most flexible of all renewable energy sources at many areas of countries. Because of, wind energy can be used in different purposes such as: irrigation, electricity generating, crop drying, grain grinding and also many other purposes and that after converting wind power to mechanical power by windmills as indicated by Ushiyama (1992).

In Egypt, wind energy is utilized for ground water lifting to irrigate small areas or generating electricity at the North West Coast of region where there are several hundreds of windmills in use for these purposes. On other hand, the survey field was conducted on about one hundred windmills to investigate the intensity of their use and problems encountered by farmers using these windmills. The survey result showed that the main problem was their small daily discharge especially during the low wind speed season. A solution of this problem can be achieved by reducing starting wind speed and increasing the discharge rate of the windmill.

The present study was carried out to improve and to evaluate the locally made windmill performance with objective of increasing water discharge and reducing the starting wind speed.

\section{REVIEW OF LITERATURE}

The most common type of windmill used for pumping water is the horizontal - axis multibladed windmill called American multibladed windmill as indicated by Hengeveld (1978). These units were still operational in many countries for cattle watering. The water resources of the North West Coast of Egypt were described by Balba (1981). He reported that ground water deep in this region ranged from 5 to $50 \mathrm{~m}$, the source of this region ranged from 5 to $50 \mathrm{~m}$, the source of this water is the rain water. Bas and Mobarak (1981) indicated that the Ministry of energy and electricity in Egypt has carried out several studies to measure the wind speed and its duration at various favorable location in Egypt. These studies determined the feasibility of using wind energy conversion system especially along the coast of the red and Mediterranean seas. The view of results showed the wind duration at Ras-Ghareb, Hurgada and Borg El-Arab. It is clear that the red sea Resort of Hurgada is an ideals site for wind farm projects with a $5 \mathrm{MW}$ station already in operation at the site. Gourieres (1982) showed that the wind energy is generally stronger over oceans than over continents. But also, the most favorable areas for wind energy production are situated on 
the continents near the sea shove. In addition, he reported that, rotor diameter of multibladed windmill ranges from 2 to $8 \mathrm{~m}$. and can start freely with winds ranging from 2 to $3 \mathrm{~m} / \mathrm{s}$. He also showed that a maximum power coefficient (Report power / wind power) of 0.3 could be obtained at tip - speed ratio (Rotor linear speed / wind speed) $\lambda=1$. However the annual average wind speed in the North West Coast in Egypt is greater than $3 \mathrm{~m} / \mathrm{s}$ for over $6750 \mathrm{hr} /$ year at El-Alamuim and over $7300 \mathrm{hr} /$ year at Bourg El-Arab as indicated by Electricity and Energy of Egypt (1982). Meel et al (1984) reported that the safety system used with the American multibladed windmill to avoid the racing of the rotor at high wind speed is eccentric system. The rotor is mounted eccentrically to the orientation axis and the spilling moment is due to the aerodynamic forces . acting on the rotor. The inclination of the rotor axis relative to the wind direction diminishes the swept area. Rao et al (1985) indicated that the performance of windmills relating the wind speed and water output as influences by the area swept by the rotors and depth of the water table was theoretically and was presented graphically. Clark and Mulh (1992) reported that American multibladed windmills operate generally at lower than wind electric generators. In addition, they found that the discharge rate of the American windmill was twice as much at the low wind speed ranged from $(3-4.5 \mathrm{~m} / \mathrm{s})$, but at high wind speed greater than $5 \mathrm{~m} / \mathrm{s}$ the wind electric system pumped more than as much water as American windmill. On other hand, two American multibladed windmills with single acting piston pump were compared by the USDA - Agric. Res service, Bush land, Taxas as reported by Clark. (1992). The main difference between the two windmills was the number of rotor blades (18 and 15 blades). The result of comparison of the discharge rate indicated that there are no significant differences between the two windmills discharge, but windmill (18 blades) discharge was slightly less than other windmill (15 blades). Hassan et al. (1994) carried out experiments on rotors with different number of blades. They found that the multibladed rotor was more efficient for low wind speed. 


\section{THEORETICAL ANALYSIS FOR READUCING STARTING} WINDSPEED OF THE WINDMILL:

Gourieres (1982) indicated that the efforts applied to the pump stroke mechanism are determined from torque transmitted to the rotor axis, as follows:

$$
\begin{aligned}
& \mathrm{T}_{\mathrm{p}_{1}}=\mathrm{K} . \text { (a) }(\mathrm{P}+\mathrm{H} . \mathrm{S} . \mathrm{W}) / \eta \\
& \mathrm{T}_{\mathrm{p}_{2}}=\mathrm{K} \text {. (a) (P) } / \eta \ldots \ldots \ldots \ldots \ldots \ldots \ldots \ldots \ldots
\end{aligned}
$$

\section{Where:}

$\mathrm{Tp}_{1}$ and $\mathrm{Tp}_{2}$ : Maximum pump torques on rotor axis of windmill at up and down trokes for single acting pump.

K: Gear ratio.

a: Radius of circle described by the end of connecting rod.

W: Specific weight of water.

S: cross-sectional area of water column.

P: Total weight of reciprocating parts

$\mathrm{H}$ : Pumping lift.

$\eta_{\text {mech }}$ : Mechanical efficiency.

On the other hand, the general equation which describes the rotor torque (due to wind) on rotor axis of the windmill as reported by Hengeveld (1978) as follows:

$$
\mathrm{T}_{\mathrm{r}}=0.5 \rho \pi \mathrm{R}^{3} \mathrm{~V}^{2} \mathrm{C}_{\mathrm{T}}
$$

\section{Where:}

$\begin{array}{ll}\text { Tr: } & \text { Rotor Torque. } \\ \rho: & \text { Air density. } \\ \mathrm{R}: & \text { Rotor radius. } \\ \mathrm{V}: & \text { Free wind speed } \\ \mathrm{C}_{\mathrm{T}}: & \text { Torque Coefficient }\end{array}$

It is Known that rotor of windmill start motion, the rotor torque $\left(\mathrm{T}_{\mathrm{r}}\right)$ must be greater than or equal to the pump torque $\left(T \mathrm{p}_{1}\right)$ at up storke for single acting pump. I.e.:

$$
\operatorname{Tr} \geq \operatorname{Tp} 1
$$

From equation (1) and equation (3) 


$$
\begin{aligned}
& \frac{1}{2} \rho \pi \mathrm{R}^{3} \mathrm{~V}^{2} \mathrm{C}_{\mathrm{T}} \geq \frac{(\mathrm{H} . \mathrm{S} . \mathrm{W}+\mathrm{P}) \mathrm{K} . \text { (a) }}{\eta_{\text {mech }}} \\
& \text { at starting mation of windmill } \mathrm{put}=\mathrm{Vs} \\
& \quad \mathrm{V}_{\mathrm{S}} \geq \sqrt{\frac{2[(\mathrm{H} . \mathrm{S} . \mathrm{W}+\mathrm{P})(\mathrm{a}) \cdot \mathrm{K}]}{\rho \cdot \pi \cdot \mathrm{R}^{3} \cdot \mathrm{C}_{\mathrm{T}} \cdot \eta_{\text {mech }}}} \ldots \ldots \ldots \ldots \ldots \ldots \ldots . . . . . . . . . .
\end{aligned}
$$

There are three attempts as shown in Fig (1) to reduce the starting wind mill in this study as follow:

\section{First attempt:}

For easy starting of windmill; the pump piston was equipped with a leak hole, a simple hole drilled through the piston as indicated by Meel and Oldenkap (1984) CWD (1987). i. e. at low speed no water was pumped, all water column above the piston passed down through the leak hole, hence the starting speed was low. In this case, the weight of water column (H. S. W) in equation (1) is equal to zero and the pump torque at up stoke $\left(\mathrm{Tp}_{1}\right)$ is:

$$
\mathrm{T}_{\mathrm{p}_{1}}=\mathrm{K} \cdot \mathrm{a} . \mathrm{P}
$$

At higher speeds the pump would gradually start pumping because of this leak hole a relatively low volumetric efficiency was to be expected. However, the first attempt in this research used to reduce the weight of water column, which is applied, by using the small cross-sectional area of deliver pipe (S).

\section{Second attempt:}

To reduce the pump torque at up stroke $\left(\mathrm{Tp}_{\mathrm{l}}\right)$, the pump of windmill was counter weight device as indicated by Gouriers (1982) and Kentfield (1988).

In this case, the counter weight or the spring arts on the lift-rod imparting an up ward force during the rise of the piston $\left(F_{c}\right)$. The intensity of the vertical force which is transmitted to the connecting rod during up stroke, is $\left[(\mathrm{P}+\mathrm{H}\right.$. S. W $\left.)-\mathrm{F}_{\mathrm{c}}\right]$. Consequently, the pump torque on rotor axis at up stroke $\left(\mathrm{Tp}_{1}\right)$ becomes:

$$
\mathrm{T} \mathrm{p}_{1}=\mathrm{K} \text {. (a) }\left(\mathrm{P}+\mathrm{H} \cdot \mathrm{S} \cdot \mathrm{W}-\mathrm{F}_{\mathrm{c}}\right)
$$

The force $(\mathrm{Fe})$ continues at act during the down stroke of the piston, but it has a resisting effect. In this case, The pump torque on rotor axis at down stroke, $\left(\mathrm{T}_{2}\right)$ which described in equation (2); its value rises to: 


$$
\mathrm{T} \mathrm{p}_{2}=\mathrm{K} \cdot(\mathrm{a}) \cdot(\mathrm{Fc}-\mathrm{P})
$$

Smoothest possible windmill rotation is obtained when the condition $\mathrm{Tp}_{1}$ $=\mathrm{Tp}_{2}$ is satisfied, i,e. when:

$$
\mathrm{F}_{\mathrm{c}}=\mathrm{P}+\frac{\mathrm{H} \cdot \mathrm{S} \cdot \mathrm{W}}{2}
$$

Then, the value of pump torque on rotor axis at up and down stroke include $(\eta$ mech $)$ is: ...

$$
\mathrm{T}_{\mathrm{p}_{1}}=\mathrm{T}_{\mathrm{p}_{2}}=\mathrm{K} \cdot(\mathrm{a}) \cdot\left[\frac{(\mathrm{H} \cdot \mathrm{S} \cdot \mathrm{W})}{2}\right]
$$

From this analysis the equation describes the starting wind speed will be determined as follows:

$$
\begin{aligned}
& \mathrm{T}_{\mathrm{r}} \geq \mathrm{Tp}_{1} \\
& \frac{1}{2} \rho \pi \mathrm{R}^{3} \mathrm{~V}^{2} \mathrm{C}_{\mathrm{T}} \geq \frac{(\mathrm{a}) \cdot(\mathrm{K})(\mathrm{H} \cdot \mathrm{S} \cdot \mathrm{W})}{2 \eta \text { mech }} \\
& \mathrm{V}_{\mathrm{S}} \geq \sqrt{\frac{2\left[\left(\frac{\mathrm{H} \cdot \mathrm{S} \cdot \mathrm{W}}{2}\right)(\mathrm{a}) \cdot(\mathrm{K})\right]}{\rho \cdot \pi \mathrm{R}^{3} \mathrm{C}_{\mathrm{T}} \eta_{\text {mech }}}}
\end{aligned}
$$

\section{Third attempt:}

Using a second pump unit with windmill in place of counter weight so that when, the first pump piston at up stroke, the second pump piston will be at down stroke and vice verse. The pump torque at up stroke of first piston can be determined by subtracting the pump torque described in equation (2) from the pump torque described in equation (1) and taking in account $(\mathrm{Pe}, \mathrm{Po})$ the weight of reciprocating part under and above the pulley of mechanism respectively as shown in the following:

$$
\begin{aligned}
\mathrm{Tp}_{1}=\frac{\left[\left(\mathrm{H} \cdot \mathrm{S} \cdot \mathrm{W}+\mathrm{P}_{\mathrm{e}}+\mathrm{P}_{\mathrm{o}}\right)(\mathrm{a}) \cdot \mathrm{K}\right]-\left[\left(\mathrm{P}_{\mathrm{e}}\right)(\mathrm{a}) \cdot \mathrm{K}\right]}{\eta \text { mech }} \\
\mathrm{Tp}_{1}=\frac{\left(\mathrm{H} \cdot \mathrm{S} \cdot \mathrm{W}+\mathrm{P}_{\mathrm{e}}\right)(\mathrm{a}) \cdot \mathrm{K}}{\eta_{\text {mech }}} \ldots \ldots \ldots \ldots \ldots \ldots \ldots \ldots \ldots \ldots \ldots \ldots \ldots \ldots \ldots \ldots \ldots \ldots \ldots \ldots \ldots \ldots \ldots \ldots \ldots \ldots \ldots \ldots \ldots
\end{aligned}
$$

\section{Where:}

Tp1 : Pump torque at up stroke of first piston

Pe and Po: weights of reciprocating parts under and above the pulley 
of mechanism.

On the other side, the pump torque at down stroke of the first piston $\left(\mathrm{Tp}_{2}\right)$ can be determined by subtracting the pump torque described in equation (2) from the pump torque described in equation (1) and also taking in account $(\mathrm{P}=\mathrm{Pe}+\mathrm{Po})$ as follows:

$$
\begin{aligned}
& \mathrm{Tp}_{2}=\sqrt{\frac{\left.(\mathrm{H} \cdot \mathrm{S} \cdot \mathrm{W})(\mathrm{a}) \cdot \mathrm{K}-\left(\mathrm{P}_{\mathrm{e}}+\mathrm{P}_{\mathrm{O}}\right) \mathrm{a} \cdot \mathrm{K}\right]}{\eta_{\text {mech }}}} \\
& \mathrm{Tp}_{2}=\frac{\left[\mathrm{H} \cdot \mathrm{S} \cdot \mathrm{W}-\mathrm{P}_{\mathrm{o}}\right](\mathrm{a}) \cdot \mathrm{K}}{\eta \text { mech }}
\end{aligned}
$$

According to equations (11) and (12) the windmill rotor always stops during the up stroke of the first piston. In this condition, the equation describes the stalling wind speed will be determined as follows:

$$
\begin{array}{r}
\mathrm{T}_{\mathrm{r}} \geq \mathrm{Tp}_{1} \\
\frac{1}{2} \rho \pi \mathrm{R}^{3} \mathrm{~V}^{2} \mathrm{C}_{\mathrm{T}} \geq \frac{(\mathrm{H} \cdot \mathrm{S} \cdot \mathrm{W}) \mathrm{a} \cdot \mathrm{K}}{\eta \text { mech }} \\
\mathrm{V}_{\mathrm{S}} \geq \sqrt{\frac{2\left[\left(\mathrm{H} \cdot \mathrm{S} \cdot \mathrm{W}+\mathrm{P}_{\mathrm{o}}\right)(\mathrm{a}) \cdot(\mathrm{K})\right]}{\rho \cdot \pi \mathrm{R}^{3} \mathrm{C} \eta \text { mech }}} \ldots . . . . . . . .
\end{array}
$$

\section{(a): Materials}

\section{MATERIALS AND METHODS}

To satisfy the objectives of this research work, a locally made windmill was prepared at Sidi Krere Alexandria West, Egypt.

The main part of the windmill is shown in Fig. (2). It has the following specifications:

Wind-mill for. using of this research locally manufactured by Military factory-99, Helwan. Egypt. The rotor of wind-mill has 15 blades and its diameter $2.43 \mathrm{~m}$. Material of blades was galvanized sheet iron. Tower of this wind-mill height was 8.6 meters Using pump of this research was piston type, its stroke $14 \mathrm{~cm}$ and its Inner diameter $7.6 \mathrm{~cm}$.

In addition, two size of delivery pipes were used, namely 1.5 inch (3.8 $\mathrm{cm}$ ) and 1 inch $(2.54 \mathrm{~cm}$ ). Gear ration 0.3 (speed of driven gear to drive gear). Pumping lift is 9.2 meter (height of water lifted from water level in well to outlet pipe level). Well of water is manually dug well at 8 meter depth and cross sectional area $2.25 \mathrm{~m}^{2}$. Counter-weight device is a weights of $25 \mathrm{Kg}$ to balance the weight of the lift-rod and piston plus half 


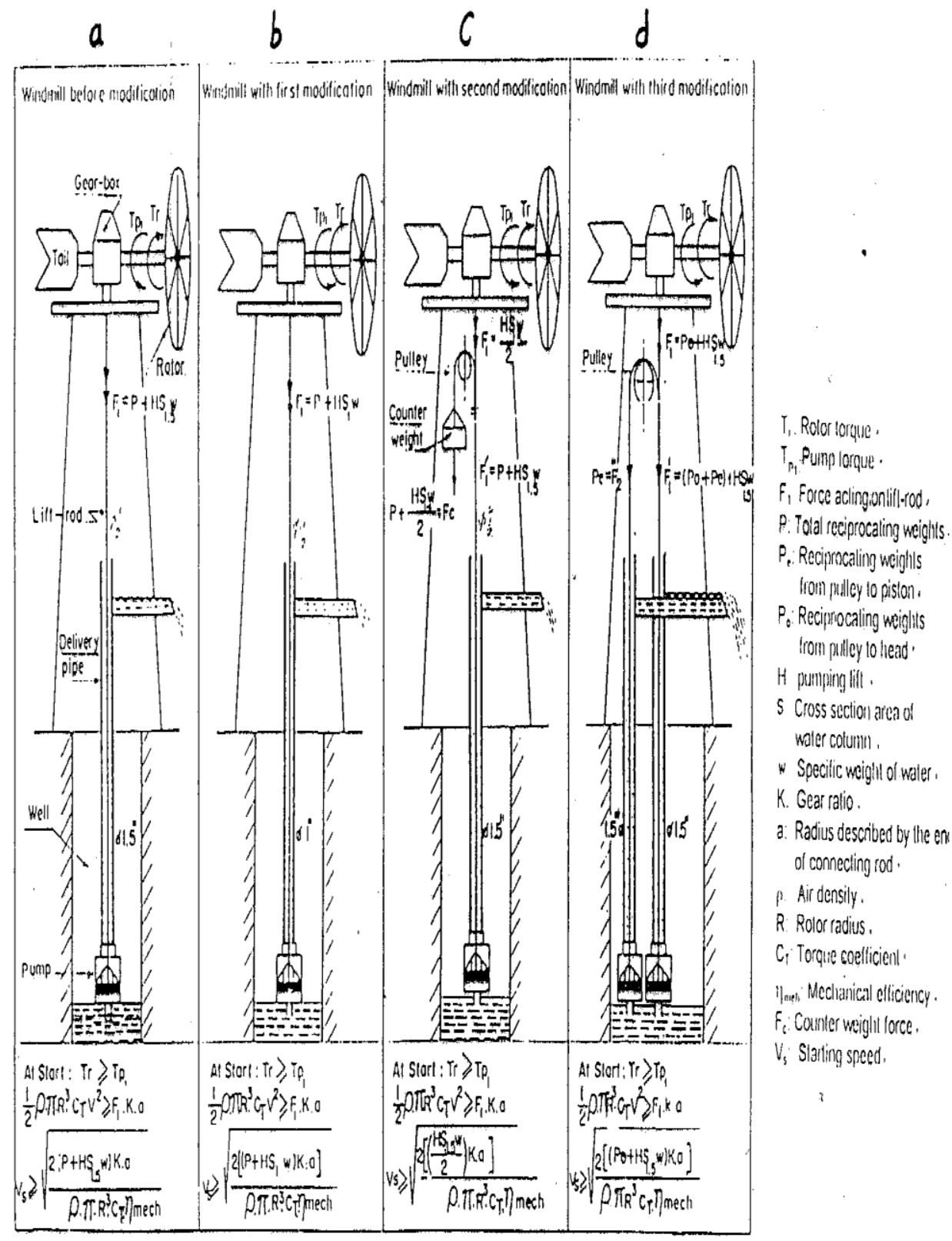

Figl1 Sketch shows the Comparison of theoretical slating windspeed for th: windmill before modificalion and after thret modifications. 


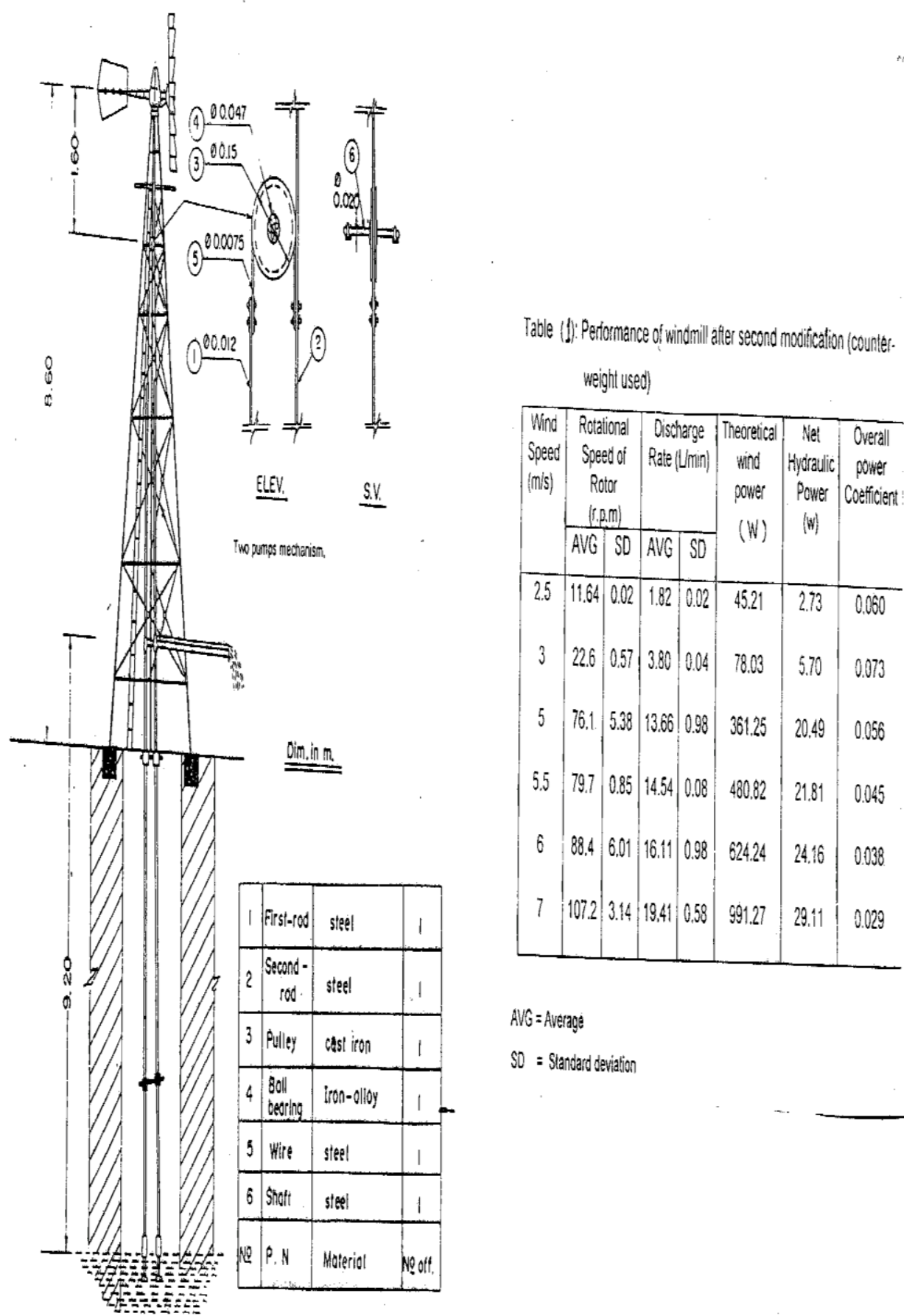

Fig. (2): Windmill with two pumps mechanism 
of the pumping load. -It was attached with the wire end of the two pumps mechanism instead of second pump unit as show in Fig. (1 b).

A two pumps mechanism was designed and installed on the windmill as show in Fig. (I $C$ ) The main parts of this mechanism are as follows: Pulley with ball bearing was outer diameter $15 \mathrm{~cm}$. In addition, a steel wire of $0.75 \mathrm{~cm}$ diameter was used, two ends of this wire are fixed to lift rood as shown in Fig. (2).

During operation of the wind-mill, having two pumps mechanism, the first lift rod goes down as the second one goes up and vice versa. An analogue cup anemometer (made in Germany-its precision $0.25 \mathrm{~m} / \mathrm{s}$ ).

measured wind speed. This anemometer was fixed on a post at the same level of wind-mill rotor axis and away about 10 meter from the windmill.

\section{(B): Methods}

Discharge rat $(\mathrm{Q})$ of the wind-mill was calculated by using the following equation:

$$
\mathrm{Q}=\frac{\text { Volume of water collected }}{\text { Time }} \quad 1 / \mathrm{min}
$$

The rotational speed of rotor $(\mathrm{N})$ was calculated by using the following equation:

$$
\mathrm{N}=\frac{\mathrm{R}_{\mathrm{c}} \cdot(60)}{\mathrm{k}} \quad \text { r.p.m }
$$

\section{Where:}

$\mathrm{R}_{\mathrm{c}}$ : Rate of delivery cycles (cycle/sec)

$\mathrm{K}$ : Gear ratio

Rate of delivery cycles $(\mathrm{Rc})$ was calculated by dividing the total number of delivery cycles by the total run time:

The Volumetric efficiency of the pump $\left(\eta_{v}\right)$ was calculated by using following equations:

$$
\begin{aligned}
& \eta_{\mathrm{V}}=\frac{\text { actual stroke valume }}{\text { Theoretical stroke volume }} \\
& \text { actual stroke valume }=\frac{\text { water collected valume }}{\text { No. of delivery cycles }}
\end{aligned}
$$




$$
\text { Theoretical stroke volume }=\frac{\pi \mathrm{D}^{2} \mathrm{p} \quad \mathrm{L}}{4}
$$

\section{Where:}

Dp: diameter of pump cylinder $(\mathrm{cm})$.

$\mathrm{L}$ : stroke Length $(\mathrm{cm})$.

The hydraulic power of the wind-mill $(\mathrm{PH})$ was calculated from the following equation as indicated by recommended by Meel et al (1984) International Energy Agency (IEA) as:

$$
\mathrm{P}_{\mathrm{H}}=\mathrm{HQW}
$$

\section{Where:}

PH: Net hydraulic Power (W)

$\mathrm{H}$ : Pumping lift (m)

$\mathrm{W}$ : Specific weight of water $(9800 \mathrm{~N} / \mathrm{m} 3)$

Theoretical wind power $(\mathrm{Pw})$ was calculated from following equation as indicated by Goureires (1982).

$$
\mathrm{P}_{\mathrm{w}}=\frac{1}{2} \rho \mathrm{S}_{\mathrm{r}} \quad \mathrm{V}^{3}
$$

\section{Where:}

Pw: Theoretical wind power (w)

$\rho:$ Air density $\left(1.25 \mathrm{Kg} / \mathrm{m}^{3}\right)$.

Sr: Swept area of rotor $\left(4.63 \mathrm{~m}^{2}\right)$.

$\mathrm{V}$ : Wind speed $(\mathrm{m} / \mathrm{s})$.

Overall power coefficient (Cpo) was calculated by followingequation:

$$
\mathrm{Cp}_{\mathrm{o}}=\frac{\mathrm{P}_{\mathrm{H}}}{\mathrm{P}_{\mathrm{w}}}
$$

\section{(C): Test Procedure}

The find out the wind-mill performance, the volume of water collected, time, number of delivery cycles and wind speed were measured simultaneously.

The persons were responsible for carrying out the experiments. The first person was responsible of reading of wind speed and time. The second person for announcing the starting ending of the run. In the same time, 
the second person collects the discharged water in a graduated flasak of capacity 18 liter. The third person records the number of delivery cycles of the run. Starting wind speed was measured at low wind speed condition $(0-3.5 \mathrm{~m} / \mathrm{s})$. The wind speed was recorded when the windmill rotor started to move. This procedure was repeated under the to the following four condition:

(a) The wind-mill with single acting pump and with a delivery pipe of 1.5 inch diameter (before modification).

(b) The windmill with single acting pump and with a delivery pipe of 1 inch diameter (first improvement attempt).

(c) The wind- mill with signal acting pump, with a delivery pipe of 1.5 inch and counter weight device (second improvement attempt).

(d) The wind-mill with two pumps and two delivery pipes of 1.5 inch (Third improvement attempt).

\section{RESULTS AND DISCUSSION}

Results is presented for the original design first then for the three modification as the following:

\section{a- Windmill performance before modification}

\section{1- Rotational speed of rotor:}

The relationship between rotor speed and wind-speed is shown in Fig (3). Results show that this relationship is a polynomial os second degree and agrees with Clark (1992). Result showed also the rotor motion at an average wind-speed $2.8 \mathrm{~m} / \mathrm{s}$ and the maximum rotor speed about 111 r.p.m at wind-speed $8 \mathrm{~m} / \mathrm{s}$ after which, the rotor is slowed by the rotor furling to avoid the racing of the rotor as the wind-speed increases

\section{2- Discharge rate:}

Results are shown in Fig. (4) where the discharge rate increased with wind-speed but this increasing decreased as wind-speed increased up to the furling speed of $8 \mathrm{~m} / \mathrm{s}$ corresponding to 111 r.p.m. rotor speed. The maximum discharge rate is obtained was $20.18 \mathrm{~L} / \mathrm{min}$ at wind-speed $8 \mathrm{~m} / \mathrm{s}$. It is worth noting that the predicted discharge rat is about $7 \mathrm{~L} / \mathrm{min}$ at wind-speed $3.5 \mathrm{~m} / \mathrm{s}$, a speed considered to represent the average annual speed for the North West Coast (Researches unit of Agri. 
Metecrology 1992).

Thus the annual discharge for the windmill before modification at pumping lift $9.2 \mathrm{~m}$ is expected to about $3700 \mathrm{~m}^{3} /$ year. The relation between discharge rate and wind-speed is similar to that of rotational speed since rotor speed is proportional to discharge rate.

The relation can be represented by the following equation (Using SAS Computer program).

\section{Where:}

$$
\mathrm{Q}=-17.56+8.88 \mathrm{~V}-0.522 \mathrm{~V}^{2} \quad\left(\mathrm{R}^{2}=0.98\right)
$$

$\mathrm{Q}$ : Discharge rate $(\mathrm{L} / \mathrm{min})$

$\mathrm{V}$ : Wind-speed $(\mathrm{m} / \mathrm{s})$

This equation covers the range of wind-speed from 2.5 to $8 \mathrm{~m} / \mathrm{s}$ at pumping lift $9.2 \mathrm{~m}$.

The negative sign is due to the starting wind-speed of the windmill is greater than Zero $\mathrm{m} / \mathrm{s}$. However this equation is of the second degree since aerodynamic losses increase with wind-speed

\section{3- Overall power coefficient of windmill:}

Overall power coefficient $\left(\mathrm{Cp}_{0}\right)$ is determined by dividing hydraulic power by wind-power. As seen in Fig. (5), the overall power coefficient $\left(\mathrm{Cp}_{\mathrm{o}}\right)$ was 0.062 at wind-speed $2.5 \mathrm{~m} / \mathrm{s}, 0.073$ at wind-speed $3 \mathrm{~m} / \mathrm{s}$ and 0.02 at wind-speed $8 \mathrm{~m} / \mathrm{s}$. The highest value $\left(\mathrm{Cp}_{\mathrm{o}}\right)$ occurred at $3 \mathrm{~m} / \mathrm{s}$ which is in agreement with Gourieres (1982) where $\lambda=0.97$.

\section{4- Volumetric efficiency of pump:}

Results of volumetric efficiency $\left(\eta_{\mathrm{v}}\right)$ versus rotor speed are given in Fig (6). The volumetric efficiencies $\left(\eta_{\mathrm{v}}\right)$ were $0.85,0.91$ and 0.94 at rotor speed $23.0,77.8$ and 109.2 r.p.m. respectively. The increase of volumetric efficiency with rotor speed within the low speed range use (max 111 r. p.m.) can be explained to be due to the decreasing leakage around the piston as indicated by sumulders and Jonhg (1994).

\section{B- Windmill performance after three modifications}

\section{1- First modification (Reducing the delivery pipe diameter):}

In this modification, reducing the delivery pipe diameter form 1.5 inch to 1 inch was expected to reduce the starting wind-speed according to the analytical study which that the water columm (a resisting force to starting) was reduced by $60 \%$. But also, results showed that practically, 


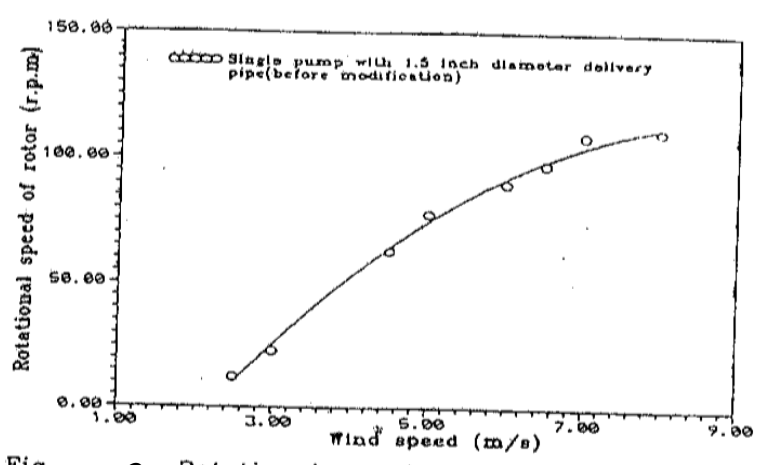

Fig. $3 \begin{gathered}\text { Rotational speed of windmill rotor versus } \\ \text { wind speed at pumping lift } 9.2 \mathrm{~m}\end{gathered}$

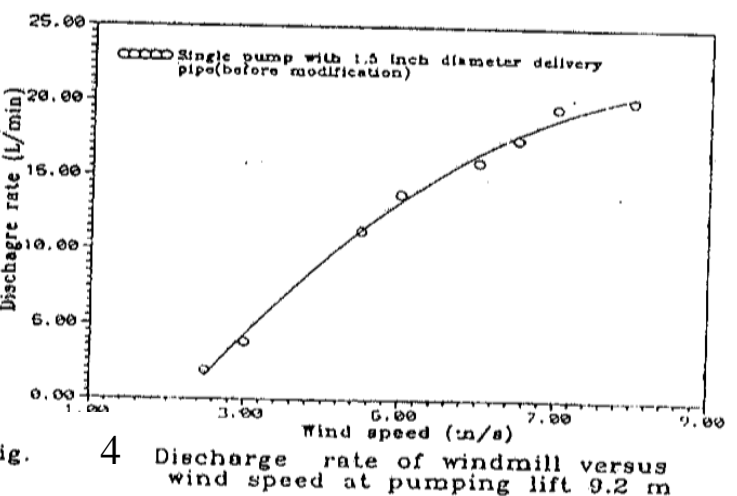

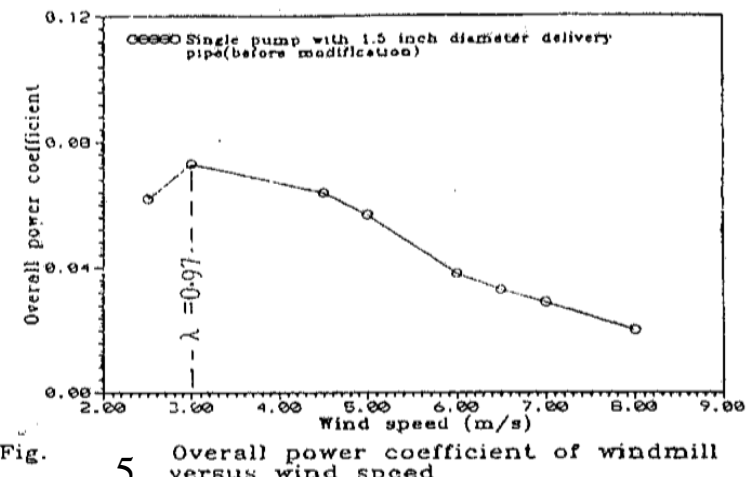

5 versus wind spoed

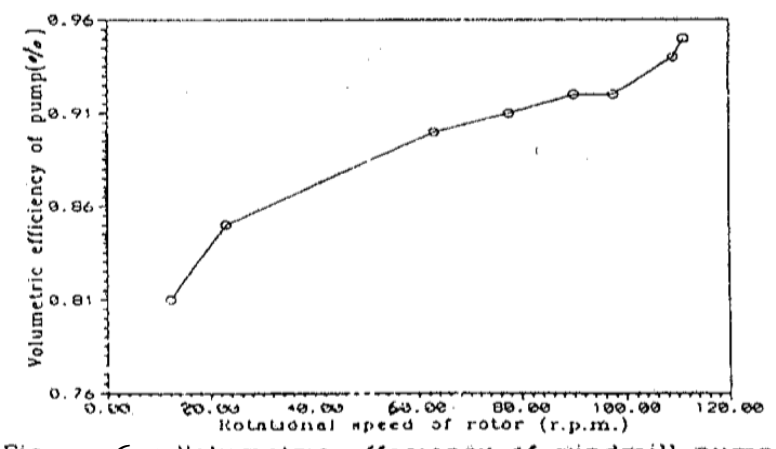

Fig. 6 voluraetric iffeciency of windmill pump 
the starting wind-speed was $3 \mathrm{~m} / \mathrm{s}$ as compared to $2.8 \mathrm{~m} / \mathrm{s}$ before modification about $7 \%$ increasing. Thus, one can conclude that, the first modification is not a practical one. It is believed that the gain due to reducing water column is offset by the increased friction between the lift rod and the new smaller delivery pipe, the lift rod was harder to pull manually and made much more noise hiliting the inside diameter during its reciprocating motion.

As to the discharge rate, there was no significant change as shown by the performance curves in Fig (7) and its equation as follows:

$\mathrm{Q}=-16.19+8.04 \mathrm{~V}-0.44 \mathrm{~V}^{2} \quad\left(\mathrm{R}^{2}=0.99\right.$ With pipe diameter $\left.1 \mathrm{inch}\right)$ The overall power coefficient $\left(\mathrm{Cp}_{\mathrm{o}}\right)$ also did not change much as shown in Fig (8). The maximum power coefficient was obtained at wind - speed $3 \mathrm{~m} / \mathrm{s}$ as that before modification.

\section{2- Second modification (Using counter weight device):}

Use of counter weight device of $25 \mathrm{Kg}$ to decrease the resisting Upward force starting the motion of the rotor gave positive results as shown in table (1).

The discharge - wind speed curve was generally not affected as expected, it almost coincided with the discharge curve before modification as shown in Fig. (9). As to the starting wind-speed, it became $1.98 \mathrm{~m} / \mathrm{s}$ as compared to $2.8 \mathrm{~m} / \mathrm{s}$ beforce modification. The reduction obtained in starting wind-speed was about $30 \%$. This is in agreement with (Kentfield, 1988) who reported in his analytical study a decrease in starting wind - speed approximately $50 \%$ is to be expected.

On the other hand, the use of counter weight, as expected did not give significant change in the discharge variation with wind-speed.

$\mathrm{Q}=-16.88+8.73 \mathrm{~V}-0.518 \mathrm{~V}^{2}\left(\mathrm{R}^{2}=0.97\right.$ With counter weight $25 \mathrm{~kg}$. $)$ The overall power coefficient $\left(\mathrm{Cp}_{\mathrm{o}}\right)$ with second modification was very much similar to that before modification as shown in Fig. (10).

However, the effect of using counter weight device on the annual operating hours of the windmill, it is clear at the annual duration curve of Bourg El-Arab i.e. the annual operating hours of the windmill can be increased approximately from 7277 to $7892 \mathrm{hr} / \mathrm{year}$ (the increasing percent about $8.4 \%$ ). 


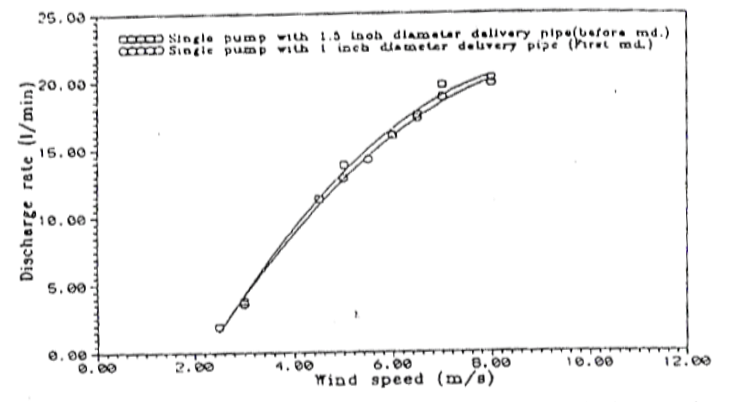

Fig. 7 Discharge rate of windmill versus wind speed

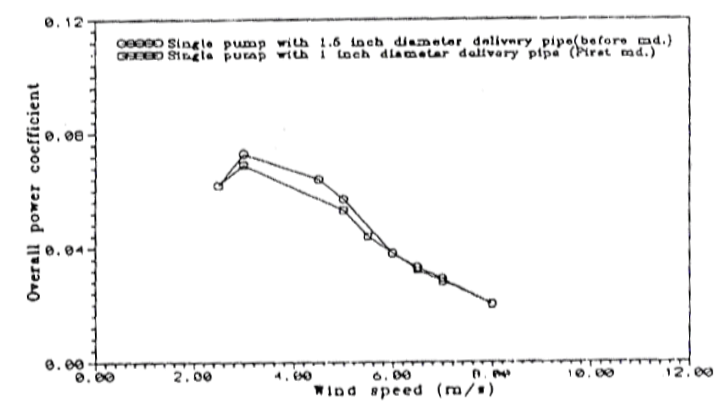

Fig. 8 verall power coefficient of nindmill versug wind speed ...........difieation

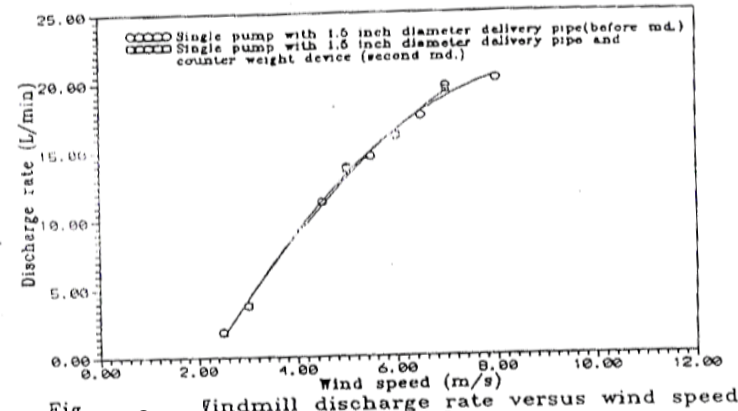

Fig 9 at pumping lift 9.2 m

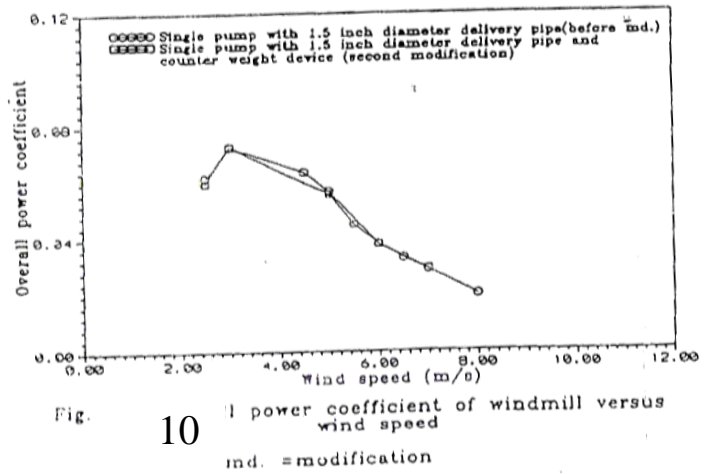




\section{3- Third modification (using two pumps mechanism):}

The use of a second pump operating is parallel with the original pump was made in order to increase the discharge rate and also to reduce the resisting starting load on the rotor, thus reducing the required starting wind-speed will be give more annual operating hours for windmill.

In this case, the second lift rod for second pump postioned in place of the counter weight. In addition, the second pump had the same design and dimensions as the first (original) pump. Theoretically the wind-speed should be increased and the starting wind-speed should also be reduced. Results of third modification is show in Fig. (11). The starting wind speed was $2.25 \mathrm{~m} / \mathrm{s}$ as compared to $2.8 \mathrm{~m} / \mathrm{s}$ before modification i.e. about $20 \%$ reduction.

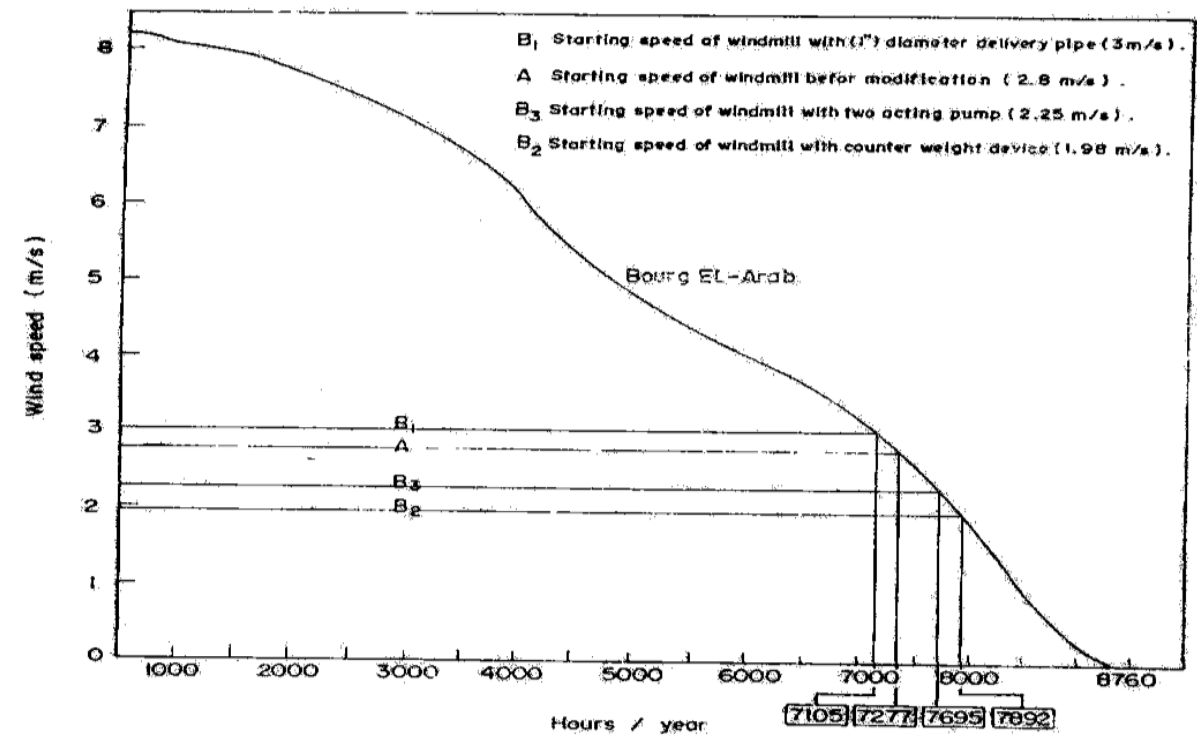

Fig.(11): Determination the annual operating hours of the windmill from the annual duration of wind-speed at Bourrg El- Arab

The discharge rate increased significantly with wind-speed. It increased from $3.8 \mathrm{~L} / \mathrm{min}$ to $5.01 \mathrm{~L} / \mathrm{min}$ at wind-speed $3 \mathrm{~m} / \mathrm{s}$ and from $20.18 \mathrm{~L} / \mathrm{min}$ to $34.47 \mathrm{~L} / \mathrm{min}$ at wind-speed $8 \mathrm{~m} / \mathrm{s}$. Thus at low wind-speed about $3 \mathrm{~m} / \mathrm{s}$ the increase of discharge was about $30 \%$ and at hight wind-speed $8 \mathrm{~m} / \mathrm{s}$ was about $70 \%$. This can be explained to be due to taking advantage of the extra power available from the rotor. The effect of two 
pumps mechanism on the discharge rate is shown also in the following equation:

$\mathrm{Q}=-29.66+14.08 \mathrm{~V}-0.738 \mathrm{~V}^{2}\left(\mathrm{R}^{2}=0.98\right.$ With two pumps mechanism $)$ The effect of two pumps mechanism on the annual operating houre is shown in Fig. (11). The annual operating hours of windmill at Bourg ElArab can be increased from 727$\} \mathrm{hr} / \mathrm{year}$ to $7895 \mathrm{hr} / \mathrm{year}$ i.e. the increase percent will be $5.6 \%$.

\section{CONLCUSION}

1- The replacing of 1 inch diameter delivery pipe instead of standard one (1.5 inch) for the first modification was to be not practical, where it gave negative results on the both the starting wind-speed and the performance of the windmill.

2- The use of counter weight device with windmill for the second modification had reduced the starting wind-speed by about $30 \%$ without change in performance of the windmill.

3- The use of two pumps mechanism with windmill for third modification reduced the starting wind-speed by about $20 \%$ and increased the discharge rate by about $30 \%$ at wind-speed $3 \mathrm{~m} / \mathrm{s}$ and by about $70 \%$ at high wind-speed $8 \mathrm{~m} / \mathrm{s}$.

4- It is clear that third modification is one of the best solutions for increasing capacity of ground water lifting windmills which are used in the North West Coast especially and low wind-speed regions generally.

\section{REFERENCES}

Balba, A.M. 1981. Agriculture development activities in the western desert of Egypt. Advances in soil and water research. Alex. Univ. No. 11:35-75.

Baz, A. and A. Mobarak. 1981. Optimal selection of windenergy conversion system of Egypt. Program of the German Egyptian workshop on solar collectors $31^{\text {st }}$ January211G February 1981, Egypt: 1-9.

Clark, R.N.1992. Performance comparison of two multibladed windmills. $11^{\text {th }}$ ASME wind Energy Symp., January: 147-149.

Clark, R.N. and K.E. Mulh. 1992. Water pumping for livestock proc. Wind power, 92 AWEA, October: 284-290.

CWD (Consultancy services wind energy Developing countries) 1987. 
The VAT 8 windmill catalogue. Netherlands.

Gourieres, D. 1982. Wind power plants-theory and design. $1^{\text {st }}$ ed fluid Mech., Univ. of Daker: (10- 1): 50-52, 151-152.

Hassan, S. O., M. S. Bayoumi, M. N. Abuelfouthouh and A. A. Hashem. 1994. Design and prototype production of small wind turbin for low wind speeds. Journal of Technology. Cairo vol. 1 No.1: 13-21

Hengeveld, H. J. 1978. Matching of wind rotors to low power electrical generators. SWD-P. O-Box 85-Amers foort the Netherlands

Kentfield, J. A. C. 1988. A new simplified water pumping wind turbine Dept. of Me ch. Eng. Calgary, Alberta, Canada T2 N IN4: 47-56.

Meel, J. V. and Odenkamp. 1984. Field performance monitoring system for water pumping windmills. Eindhoven Univ. of Technology Eindhoven, Netherlands: 255-266.

Ministry of Electricity and Energy 1982. National strategy for development and unitization of new and renewable sources of energy (NRSE): Abasya, Cairo, Author: 3-10.

Rao, R., B. Sharma and P. Chowdhry. 1985. Deign charcteridtes and performance of windmills - Agricultural Mechanization in Asia Africa and Latin- Amric. Vo1.16, No. 2:27-29.

Sumulders, P. T. and J. D. Jongh 1994. Wind water pumping. Status. Prospects and barriers. $\mathrm{Pb}$ in Netherlands by Renewable Energy, Vol.5, No. 1: 587-594.

Ushiyama, Izumi 1992. Development of a simplified wind power water pumping system in Indonesia, Wind Engineering, Japan Vol. 16, No. $1: 1-3$.

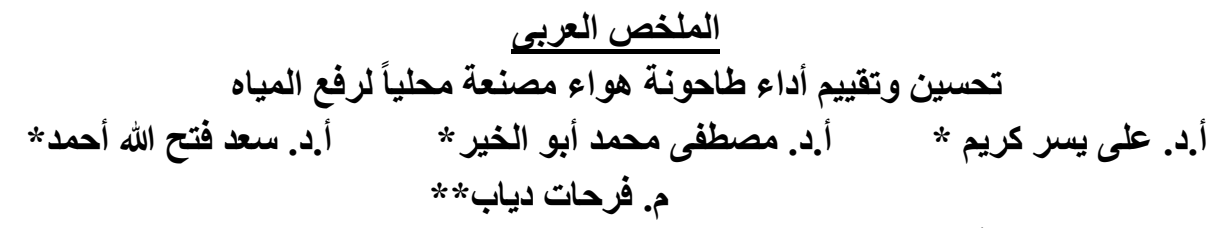

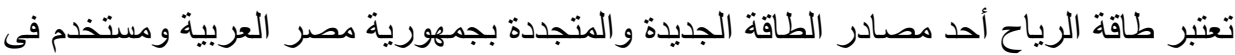

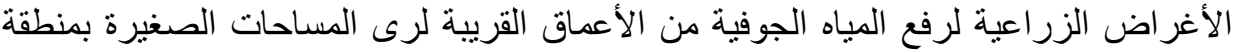

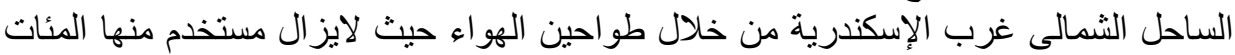
نظر اً لتفضيل العديد من المز ارعين استخدام تلك الوسيلة لرفع المياه طبقاً للمسح الميدانى لمائة المئة طاحونة هو اء بتلك المنطقة.

* * أستاذ بقسم الهندسة الزر اعبة، كلية الزر اعة. جامعة الإسكندرية

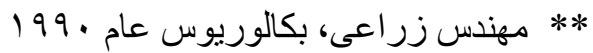


وقد أظهرت نتائج المسح الميدانى أن المشكلة الرئيسية التى تواجها تللك الطواحين تتحصر فى قلة التصرف اليومى للمياه وخصوصاً عند سرعات الرياح المنخفضة مع ضرورة إمكانية تشغيل تلك الطواحين عند سرعات الرياح المنخفضة بسهولة، ولهذا تضمنت الدراسة البحثية ثناث تحسينات لتطوير أداء طاحونة هو اء حيث أجريت التجارب على طاحونة هو اء ذات طلمبة مفردة مصنعة محلياً ومستخدمة بمزرعة خاصة بمنطقة سيدى كرير - غرب الإسكندرية وقد فئد تضمن البحث تقييم أداء تلك الطاحونة قبل أى تعديل مع إدخال ثنلاث تعديلات منفصلة لتطوير

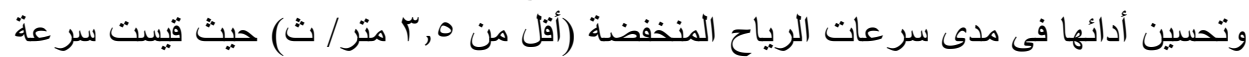

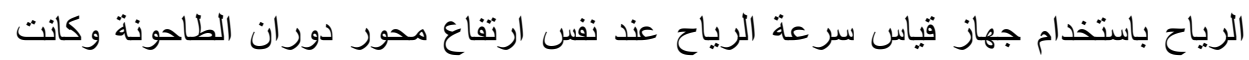

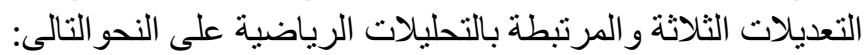

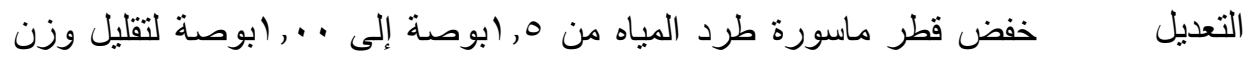

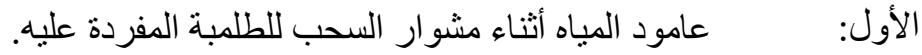

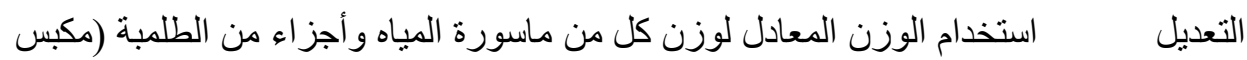

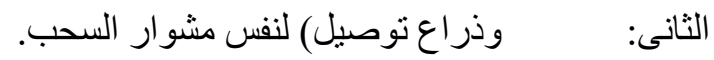

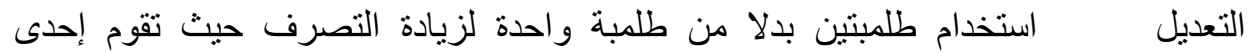

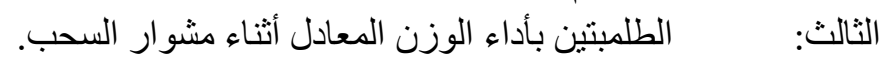
وقد أوضحت النتائج الآتى:

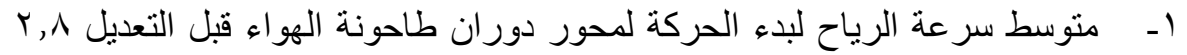

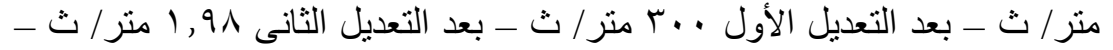

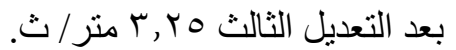

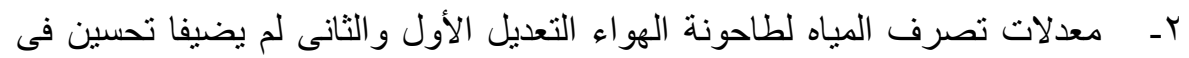

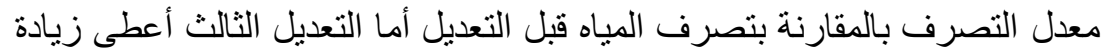

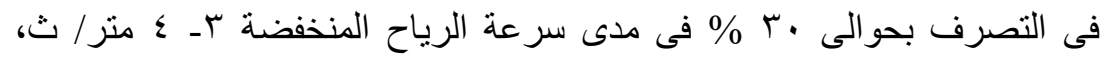

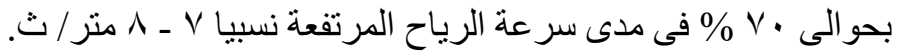

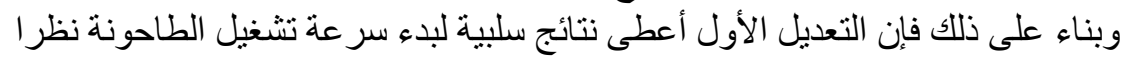

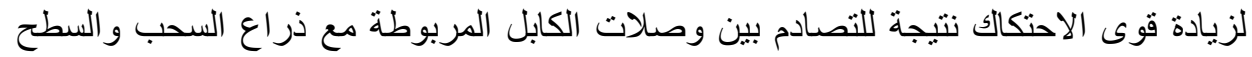

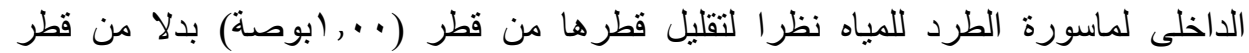

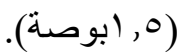

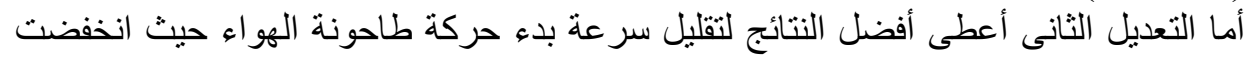

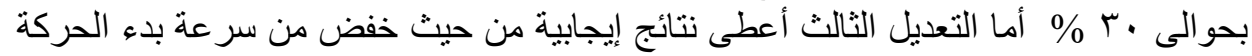

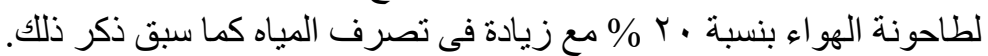

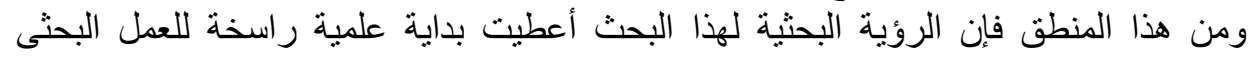

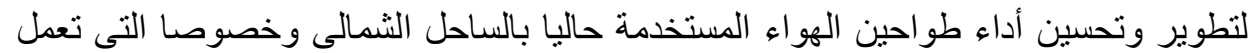
على سر عات رياح منخفضة. 